\title{
Two new species of Begonia sect. Erminea (Begoniaceae) from Nosy Mangabe in Madagascar
}

\author{
David Scherberich \& Jacky Duruisseau
}

\begin{abstract}
SCHERBERICH, D. \& J. DURUISSEAU (2017). Two new species of Begonia sect. Erminea (Begoniaceae) from Nosy Mangabe in Madagascar. Candollea 72: 257-263. In English, English and French abstracts. DOI: http://dx.doi.org/10.15553/c2017v722a3

Begonia nosymangabensis Scherber. \& Duruiss. and Begonia pteridoides Scherber. \& Duruiss. are described and illustrated. Both new species belong to Begonia sect. Erminea A. DC. Begonia nosymangabensis is compared to Begonia keraudreniae Bosser, from which it differs in having larger and more deeply incised leaves which lack adaxial hairs. Begonia pteridoides is related to Begonia bogneri Ziesenh. but differs by its very divided leaves. Both new species are micro-endemics, restricted to Nosy Mangabe island in northeast Madagascar and are assessed as "Vulnerable" according to the IUCN Red List Categories and Criteria.
\end{abstract}

\section{Résumé}

SCHERBERICH, D. \& J. DURUISSEAU (2017). Deux nouveaux Begonia sect. Erminea (Begoniaceae) de Nosy Mangabe à Madagascar. Candollea 72: 257-263. In English, English and French abstracts. DOI: http://dx.doi.org/10.15553/c2017v722a3

Begonia nosymangabensis Scherber. \& Duruiss. et Begonia pteridoides Scherber. \& Duruiss. sont décrits et illustrés. Les deux nouvelles espèces appartiennent au genre Begonia sect. Erminea A. DC. Begonia nosymangabensis se rapproche de Begonia keraudreniae Bosser, dont il diffère par ses feuilles plus grandes et plus profondément incisées et l'absence de poils à la face adaxiale. Begonia pteridoides est apparenté à Begonia bogneri Ziesenh., mais en diffère par ses feuilles très divisées. Les deux nouvelles espèces sont des micro-endémiques, restreintes à l'île de Nosy Mangabe au nord-est de Madagascar et sont considérées comme «Vulnérables» selon les Catégories et Critères de la Liste Rouge de l'UICN.

\section{Keywords}

BEGONIACEAE - Begonia - Madagascar - Masoala - Nosy Mangabe - Taxonomy

\footnotetext{
Addresses of the authors:

DS: Jardin Botanique de Lyon, Mairie de Lyon, 69205 Lyon cedex 01, France. E-mail: david.scherberich@mairie-lyon.fr

JD: rue de La Romade 24, 17240 Bois, France.
} 


\section{Introduction}

Begonia L. is one of the largest genera of angiosperm, comprising as of today 1839 recognized species (HugHes et al., 2015-). Although many new species of this genus are discovered and published every year, only two have been described from Madagascar since the publication of the Begoniaceae revision in the Flore de Madagascar et des Comores (KeraudrenAymonin, 1983). Both are endemic to the Masoala peninsula in northeast Madagascar. One of these is the very unique B. masoalaensis M. Hughes which doesn't seem to be related to any other Malagasy species, with a combination of a tuberous stem, an unusual inflorescence structure which is spicate and terminal with two main axes, and fleshy fruits with axile placentation (Hughes, 2011). Another novelty was described last year, B. henrilaportei Scherber. \& Duruiss., a lithophytic species with a creeping stem, related to B. lyallii A. DC. but with lanceolate, pinnately veined leaves (Scherberich \& DuruisSEAU, 2016). The specific epithet of that later species honors Henri Laporte, a French Begonia collector who discovered and introduced in cultivation many novelties from the Masoala area. Two of these are described here, increasing the number of accepted Malagasy Begonia species to 52. Madagascar's forests are among the most biologically rich and unique in the world and it is very certain that as more areas become accessible, exploration will reveal more new discoveries. Both new species here described are known only from Nosy Mangabe which is a very small island of 520 ha in the Antongil Bay, $5 \mathrm{~km}$ south of the town of Maroantsetra. It is a protected reserve which is part of the Masoala National Park and is entirely covered with rainforest vegetation. It is also the habitat of Begonia erminea L'Hér. and the herbarium collections studied so far seem to indicate that this species is also restricted to the island. Other families are also known to have micro-endemic species in Nosy Mangabe such as Impatiens nosymangabensis Eb. Fisch. \& Raheliv. and I. carlsoniae Eb. Fisch. \& Raheliv (Fischer \& Rahelivololona, 2007). The cultivation of both Begonia nosymangabensis Scherber. \& Duruiss. and B. pteridoides Scherber. \& Duruiss., which are adapted to a very high level of humidity, require a terrarium where warm and humid conditions can be provided. Both new species are described here, their affinities with closely related species are discussed and diagnostic characters are given. We provide detailed line drawings and close-up pictures from living material. Their distribution and ecology are also provided as well as preliminary IUCN conservation status assessments.

\section{Systematics}

Begonia nosymangabensis Scherber. \& Duruiss., spec. nova (Fig. 1, 3E-F).

Typus: [Madagascar. Prov. Toamasina]: Plant in cultivation in Lyon Botanical Garden under $n^{\circ} 100651$, originally collected by H. Laporte in 1998 in Nosy Mangabe, 10.V.2016, Scherberich 1132 (holo-: LYJB!; iso- : G!, P!, TAN!).

Begonia nosymangabensis Scherber. E' Duruiss. can be compared with B. keraudreniae Bosser but differs by the larger size with more leaves (5-25 vs 1-3) which are longer and narrower (7-15 cm vs 3.5-6.5 cm long), more deeply incised, without spiculiform hairs adaxially and a longer stem (2-7 cm vs 1-3 cm). It could also be compared to B. nana L'Hér. and $B$. lemurica Keraudren but differs from both by the presence of a stem, from the former by the deeply lacerate-incised blades, and from the later by the larger lamina $(5-9 \times 2-3.5 \mathrm{~cm}$ vs $3.5 \times 3 \mathrm{~cm}$ ) with more primary lateral veins (3-4 vs 1 pair) and a higher number of stamens (10-14 vs 8).

Tuberous perennial lithophytic herb with short upright clustered stems. Tuber small, 20-30 mm, irregular, strongly adherent. Stem herbaceous, 2-7 cm, red; internodes 0.6-1.5 $\mathrm{cm}$. Stipules persistent, the margins entire. Leaves 5-25, alternate, sometimes pseudo-distichous, straight; petiole $2-4.7 \mathrm{~cm}$ long, 1.5-2 mm diam., cylindrical, slightly flattened on adaxial side, glabrous, red; blade 5-9 × 2-3.5 cm, symmetric to slightly asymmetric, oblanceolate to obtrullate, deeply lacerate-incised, mucronulate in upper $2 / 3$, the base acute, entire, the apex narrowly acuminate, serrate, the margins revolute, light green and semiglossy to subvelvety adaxially, paler and semiglossy abaxially; midrib and primary lateral veins slightly raised adaxially, very prominently raised and pale red abaxially; primary lateral veins 3-4 per side, arising at an angle of $10-20^{\circ}$. Inflorescence a dichasial cyme, axillary, bearing 5-6 flowers at summit, bisexual, protandrous, with basal male flowers and a solitary distal female flower; inflorescence axis $5.5-9.5 \mathrm{~cm}$ long, 1.2$1.6 \mathrm{~mm}$ diam.; bracts present at anthesis, eventually caducous, lanceolate, 3-4 × 1.5-2.5 mm; bracteole absent; perianth segments pink, paler at the apex. Male flower perianth segments 4, free, peduncle 9-12 $\mathrm{mm}$; outer perianth segments elliptic-obovate, apex obtuse, $8.4-9 \times 5.5-7 \mathrm{~mm}$; inner perianth segments oblanceolate 8-8.5 × 3-3.5 mm, paler; stamens (9-)10-14 $(-17)$; androecium zygomorphic; filaments fused at the base into a column 0.5-0.7 mm long; free part 0.8-0.9 $\mathrm{mm}$; anthers longer than filament, oblong, 1.4-1.7 mm, dehiscent through lateral longitudinal slits; connective not extended. Female flower perianth segments (5-)6, free; peduncle 11-13 mm; outer perianth segments oblanceolate-obovate, apex obtuse, 9-10.5 × 3.6-6.4 mm; inner perianth segments oblanceolate, 8.5-11 $\times 3.5-4 \mathrm{~mm}$, paler; ovary 3 -winged, unequal, with one 


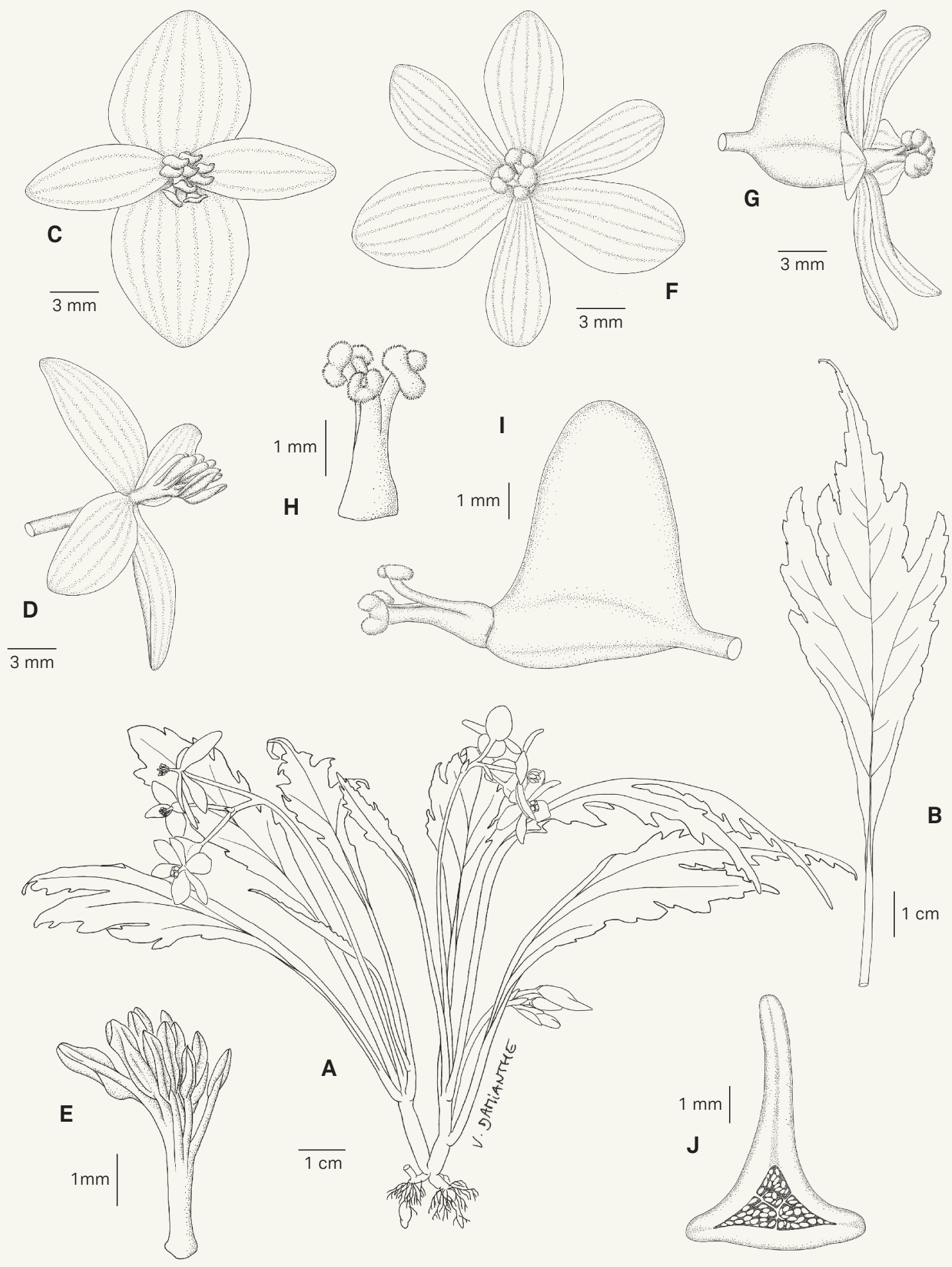

Fig. 1. - Begonia nosymangabensis Scherber. \& Duruiss. A. Habit; B. Leaf, adaxial side; C. Male flower, front view; D. Male flower, side view; E. Androecium; F. Female flower, face view; G. Female flower, side view; H. Styles and stigmas; I. Ovary; J. Ovary cross-section. [Scherberich 1132, LYJB] [Drawing: Vanessa Damianthe] 

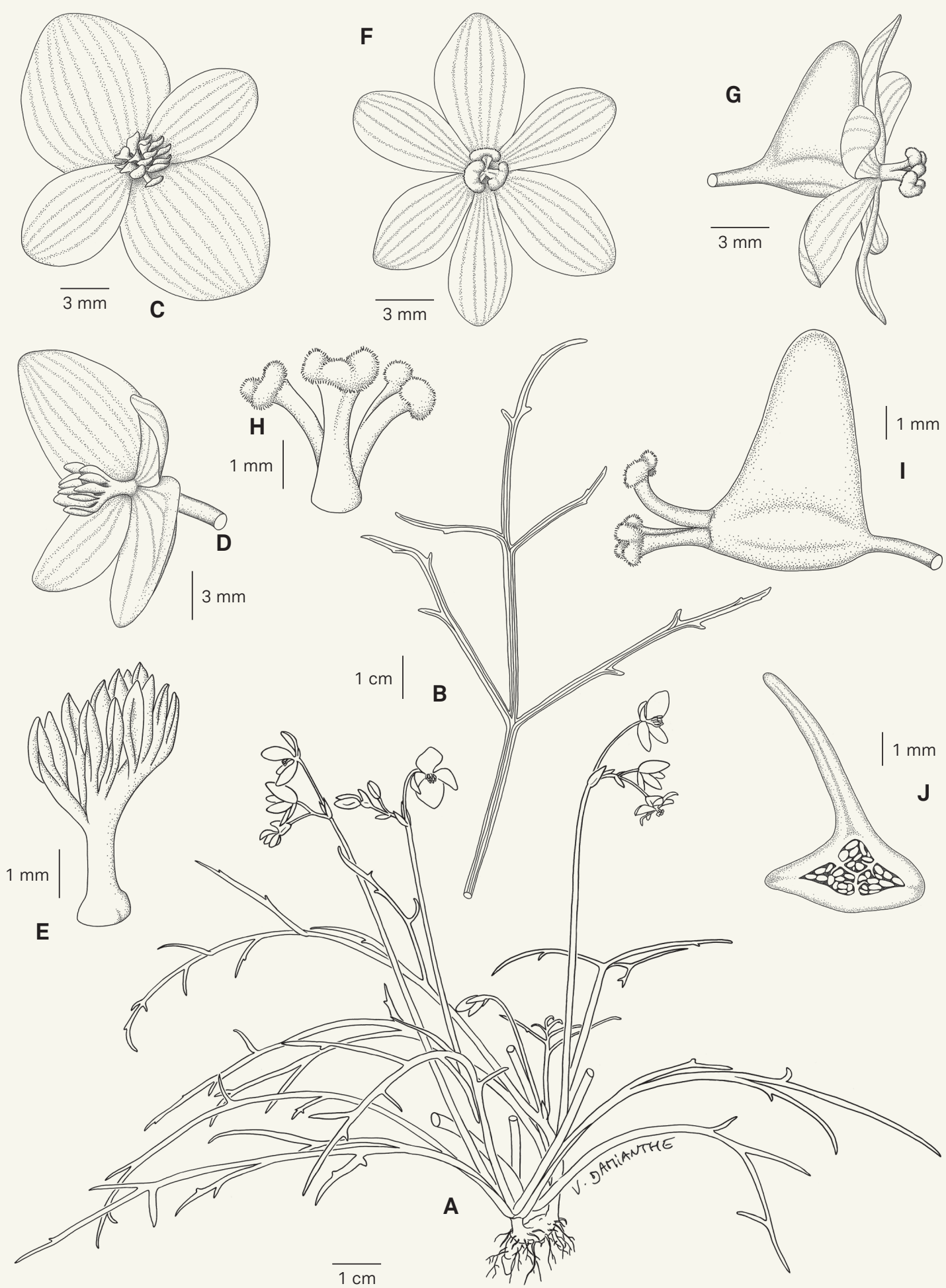

Fig. 2. - Begonia pteridoides Scherber. \& Duruiss. A. Habit; B. Leaf, adaxial side; C. Male flower, front view; D. Male flower, side view; E. Androecium; F. Female flower, face view; G. Female flower, side view; H. Styles and stigmas; I. Ovary; J. Ovary cross-section. [Scherberich 1148, LYJB] [Drawing: Vanessa Damianthe] 
wing conspicuously larger than the two others, red-brown, composed of 3 locules; placentae septal, bi-lamellate; ovules numerous, white; styles 3, fused halfway, bifid, white to pale yellow, persistent in fruit; stigma reniform, in a band, yellow; Fruit a 3-winged dry capsule, nodding, the wings unequal. Seeds ovoid, $0.4-0.5 \times 0.2 \mathrm{~mm}$, tegument reticulate.

Distribution and ecology. - Known only from the type collection in Nosy Mangabe, Madagascar, where it grows on mossy granite boulders in stream beds, at low elevation. It has been found growing in association with $B$. erminea L'Hér. and a suspected natural hybrid between both has been observed. Flowering in cultivation has been observed most of the year as long as humid and warm conditions are provided.

Conservation status. - The island of Nosy Mangabe is a protected area, with a surface of $5.2 \mathrm{~km}^{2}$ and is included in the Masoala National Park. As B. nosymangabensis is restricted to this small island, it has a very small area of occupancy. As such, eco-tourism and illegal collectors could have a rapid negative impact on the conservation of this new species. In regards that the new species has a population with a very restricted area of occupancy $\left(<20 \mathrm{~km}^{2}\right)$, the conservation status as "Vulnerable" [VU D2] is proposed following the IUCN Red List Categories and Criteria (IUCN, 2012).

Notes. - Some herbarium specimens from Nosy Mangabe, which were initially thought to represent another undescribed species, could in fact be B. nosymangabensis although they have a slightly different morphology. They have longer stems without basal leaves and the blades are narrower with more profound lobes (Schatz 1904, MO, P,TAN and Du Puy MB147, K, TAN). Although B. nosymangabensis has been in cultivation for 15 years and has been reproduced by seeds occasionally, no plant has ever shown the characteristics of these specimens. B. nosymangabensis belongs to section Erminea. The male and female flowers with 4 and 6 tepals respectively, the presence of a staminal column and the 3 bifid styles are typical of that section.

Begonia pteridoides Scherber. \& Duruiss., spec. nova (Fig. 2, 3A-D).

Typus: [Madagascar. Prov. Toamasina]: Plant in cultivation in Lyon Botanical Garden under $n^{\circ}$ 080405, originally collected by H. Laporte in 2001 in Nosy Mangabe, 21.IX.2016, Scherberich 1148 (holo- : LYJB!; iso- : G!, P!, TAN!).

Begonia pteridoides Scherber. \& Duruiss. is similar to B. bogneri Ziesenh. but differs by its highly divided leaves (vs entire linear leaf blades). Begonia pteridoides also differs from B. monicae Aymonin E Bosser, both having bipinnatifid leaves, by its less divided leaves and much longer lobes and the number of stamens (9-15 vs 25-30).
Tuberous perennial lithophytic herb with short clustered stems and spreading to pendulous leaves. Tuber small, 10$20 \mathrm{~mm}$, irregular, strongly adherent. Stem herbaceous, to $2 \mathrm{~cm}$, red; internodes short 1-5 mm; Stipules persistent, the margins entire. Leaves 5-8, alternate, straight; petiole 4-12 mm long, 1-1.5 mm diam., hardly distinguishable from blade, cylindrical, slightly flattened on adaxial side, glabrous, red; blade 5-15 cm long, with twice-divided filiform segments 1-2 mm wide, segments 2-4 per side, arising at an angle of $40-50^{\circ}$, alternating every $0.2-2 \mathrm{~cm}$, getting smaller toward apex, acute, the lower primary segments $2-6 \mathrm{~cm}$ long, light green and semiglossy adaxially, paler and glossy abaxially; midrib and primary lateral veins slightly raised adaxially. Inflorescence a monochasial cyme, axillary, bearing 3 flowers at summit, bisexual, protandrous, with basal male flowers and a solitary distal female flower; inflorescence axis 4.5$8.5 \mathrm{~cm}$ long, 1-2 mm diam.; bracts present at anthesis, eventually caducous, lanceolate, $2.5-3 \times 1.5-2.5 \mathrm{~mm}$; bracteole absent; perianth segments pink. Male flower perianth segments 4 , free, peduncle 9-17 $\mathrm{mm}$; outer perianth segments sub-orbicular to elliptic-lanceolate, rounded at apex 5.2-6 $\times$ 8.7-9.5 mm; inner perianth segments obovate-oblanceolate 7.5-9.4 × 3.4-4.2 mm, paler; stamens 9-15; androecium zygomorphic; filaments fused at the base into a column 0.8-1 mm long, free part $0.5-1 \mathrm{~mm}$; anthers longer than filament, oblong, $1.5 \mathrm{~mm}$, dehiscent through lateral longitudinal slits; connective not extended. Female flower perianth segments 6(-7), free; peduncle $10-12 \mathrm{~mm}$; outer perianth segments obovate, apex obtuse, $6.5-8 \times 4.2-5 \mathrm{~mm}$; inner perianth segments oblanceolate, $7-8 \times 3.2-4 \mathrm{~mm}$; ovary 3 -winged, unequal, with one wing conspicuously larger than the two others, 5-7 $\mathrm{mm}$ long versus 2-2.5 $\mathrm{mm}$ long, green to red-brown, composed of 3 locules, placentae septal, bi-lamellate; ovules numerous, white; styles $3(-4)$, fused $1 / 3$ to halfway, pale yellow, persistent in fruit; stigma reniform, in a band, yellow; Fruit a 3-winged dry capsule, nodding, the wings unequal. Seeds unknown.

Distribution and ecology. - Known only from the type collection in Nosy Mangabe, Madagascar, growing on mossy granite boulders. Flowering in cultivation has been observed from September to June.

Conservation status. - The locus classicus has never been relocated since the original collection and as $\mathrm{H}$. Laporte died shortly after his return from Madagascar, the information regarding the collection locality was given by his guide Paul Clément Harimalala. As B. pteridoides is restricted to Nosy Mangabe and as such has a very restricted area of occupancy which is typically $<20 \mathrm{~km}^{2}$, the conservation status as "Vulnerable"[VU D2] is proposed following the IUCN Red List Categories and Criteria (IUCN, 2012). 

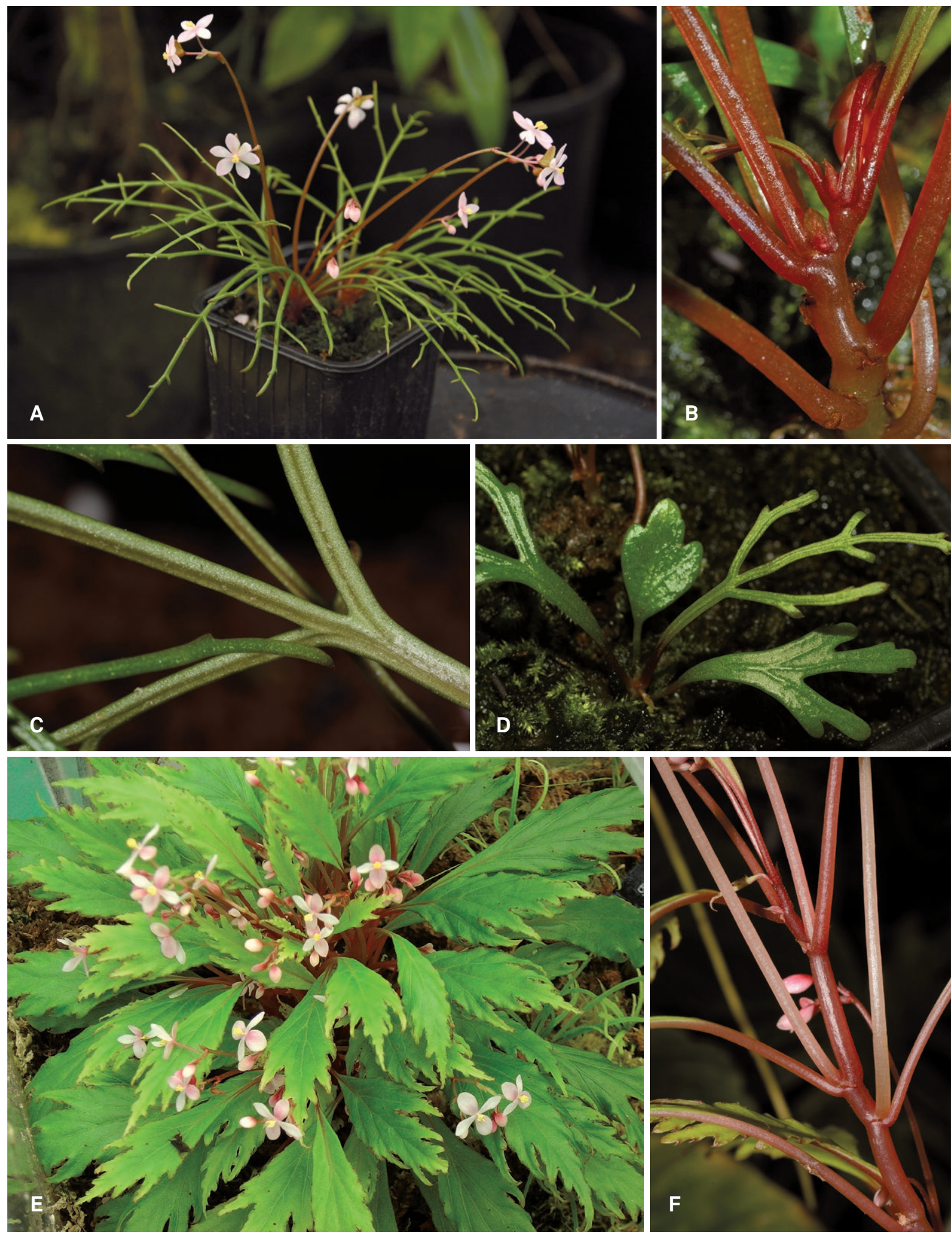

Fig. 3. - Begonia pteridoides Scherber. \& Duruiss. (A-D) and Begonia nosymangabensis Scherber. \& Duruiss. (E-F).

A. Habit in cultivation; B. Stem; C. Leaf, abaxial side; D. Young plant showing juvenile leaves; E. Habit in cultivation; F. Stem. [Photos: A-D, F: David Scherberich; E: Evelyne Bouquet] 
Notes. - Begonia pteridoides was collected by H. Laporte on his last trip to Madagascar, just before he died of a severe form of malaria. It has never been recollected since and unfortunately no herbarium specimens have been sourced. Over the years, living plants have been shared with Begonia collectors and although it is a very tricky plant to keep alive, it is still present in a few specialized collections and among terrarium growers. The habit is erect in cultivation but a picture taken in situ by $\mathrm{H}$. Laporte, shows a colony of plants growing on granite, with pendent leaves. That habit could reflect a reaction to a momentarily dry period.

\section{Acknowledgements}

The authors would like to thank the curators of G, K and P for allowing access to the collections as well as Marc Hughes and Martin W. Callmander for their careful review of the original version of this article and their suggested improvements. The authors are also grateful to Vanessa Damianthe for the beautiful line drawings, and Evelyne Bouquet who is in charge of the living collection of Begonia at the Jardin Botanique de Lyon, for taking care of the plants in cultivation, and for her willingness to help with observations on the cultivated plants.

\section{References}

Fischer, E. \& M.E. Rahelivololona (2007). New taxa of Impatiens (Balsaminaceae) from Madagascar IV. Adansonia ser. 3, 29 : 269-315.

Hughes, M. (2011). A new species of fleshy-fruited Begonia (Begoniaceae) from the Masoala Peninsula, Madagascar. Adansonia ser. $3,33: 81-85$.

Hughes, M., P. Moonlight, A.Jara \& M. Pullan (2015-). Begonia Resource Centre [http://padme.rbge.org.uk/begonia].

IUCN (2012). IUCN Red List Categories and Criteria : Version $3.1 \mathrm{ed}$. 2. IUCN Species Survival Commission, Gland and Cambridge.

Keraudren-Aymonin, M. (1983). Bégoniacées. In : Leroy, J.-F. (ed.), Fl. Madagascar Comores 144.

Scherberich, D. \& J. Duruisseau (2016). Begonia henrilaportei Scherber. \& J. Duruisseau (Begoniaceae), a new endemic species from the Masoala peninsula, Madagascar. Candollea 71 : 11-16. DOI : http://dx.doi.org/10.15553/c2016v711a3 